\title{
TIBF THE DYNAMICS OF CREDIT QUALITY AND IMPLICATIONS FOR THE PRICING OF SMALL BUSINESS LOANS
}

\author{
Adrian M. Cowan and Charles D. Cowan \\ St. Mary's University, San Antonio and The University \\ of Alabama, Birmingham
}

\begin{abstract}
We analyze the implications of the dynamics of credit scores for small businesses; strategies for banks to maximize revenues; and Basel II minimum capital requirements on loan pricing for loans to small firms that do not have access to capital markets. Relating dynamic changes in the competitive environment to pricing decisions also provides a contribution to the literature. A theoretical model is developed to investigate the differences between relationship and transactional lending to small businesses in the context of these factors in the banking industry. The model demonstrates that in highly competitive markets, each type of lender occupies overlapping spaces, and can be simultaneously attractive to different types of borrowers if banks take advantage of their knowledge of the dynamics.
\end{abstract}

Keywords: Credit scoring, Loan pricing, Small business lending, Basel II JEL Classification: G21, D81, L14

\section{Introduction}

Banks that compete for small business loans follow two basic operational strategies: relationship and transactional lending. Boot and Thakor (2000) had argued that the degree to which a bank will engage in relationship lending relative to transaction lending is a function of technology, competition, and regulation, among other factors. However, their argument had only considered a single time period. Analysis of a longer "relationship" shows that the degree to which banks can and will engage in relationship lending is broader than first thought.

The dynamics of small business credit worthiness also has implications for the impact on the small business loan markets. We consider how the dynamics impact the competitive loan pricing of small business loans. Such themes we consider are how these dynamics may impact loan pricing, whether small businesses strategically target banks to obtain the best value possible, or vice versa, the analyzing the behavior of banks targeting specific groups of borrowers. The goal of our analyses is to investigate these questions and the implications of the dynamics of credit 
scores for both the banks and their small business customers. A model that captures the complexity of credit scoring on small business loan pricing when considering the dynamics surrounding the market and the changing characteristics of borrowers will be introduced as well, further justifying our claims.

Section 3 discusses the competitive environment in which banks must compete with one another, while in Section 4, we develop our basic model with corresponding results of this model in section 5 for individual points in time. We present our extended results in Sections 6 and 7 where relationship bankers are shown to be able to compete effectively at several levels with each other and with transactional lenders. Section 8 provides the empirical and policy implications of our model, while Section 9 concludes our work.

\section{The Competitive Environment for Small Business Loans}

\subsection{Credit Scoring}

Small business credit scoring (SBCS) has been in use in lending for more than a decade. The implementation of SBCS differs between banks, yet many banks use some form of credit score, whether purchased from a third party or computed from the borrower's data. The recognition that business owner characteristics outperform business characteristics as predictors for very small commercial loan performance supported the application of credit scores to small firms with minimal or no credit history (see Mester, 1997). Additionally, third party vendors of SBCS, which began in 1995 with Fair Isaac's Small Business Scoring Service, further extended the availability of this technology for banks with limited resources for analysis.

As banks extract a signal from a credit score, the informational asymmetry between banks as described by Sharpe (1990) is greatly reduced. Despite SBCS, informational asymmetries persist between borrowers and lenders (Diamond, 1984). During the lending process, banks may integrate credit scores in several ways. Whereas some banks use the credit score exclusively in the lending decision, others adopt a mixture of credit scoring with relationship lending. Other banks have not integrated the use of SBCS at all and continue to use only relationship lending with a more traditional underwriting approach. In addition, the approach may differ within the same bank by loan size, business sector, or region. Alternative implementation strategies are found in the empirical literature: Akhavein, Frame, and White (2005); Frame, Srinivasan, and Woosley (2001); Berger and Udell (2002); Cole, Goldberg, and White (2004); Cowan and Cowan (2006). The different approaches introduce a complicated framework with the analyses focusing upon a single time period.

Blöchlinger and Leippold (2006) had presented a model of loan pricing within the context of internal credit rating systems. To the best of our knowledge, this is the only theoretical paper that examines credit scoring in the context of loan pricing. The focus of that paper was on the development of internal ratings models and the relationship between the lending decision and the quality of that model.

\subsection{BASEL II}

During the progression of SBCS development, the Basel Committee has been updating capital requirements on small and medium size enterprise loans to more 
closely reflect the risk inherent in these loans. Basel II provides several alternative approaches to the measurement of capital requirements based on credit risk. The three approaches for credit risk involve the standardized approach and two separate internal ratings based (IRB) approaches (i.e., foundation IRB and advanced IRB). The two IRB approaches differ primarily by the expansion of parameters estimated by banks in the advanced approach. At a minimum under the foundation IRB, banks estimate the probability of default.

There has been a good deal of discussion in the industry regarding the competitive advantage offered to those banks that are able to adopt the IRB, and in particular, A-IRB. It is expected that the adoption of the IRB approach of Basel II will lead to a reduction in the minimum capital requirement for small business lending: see Repullo and Suarez (2004) and Berger (2004).

Repullo and Suarez (2004) had presented a theoretical model predicting that loan pricing is impacted through the reduction of the capital requirements with the IRB approach when moving from Basel I to Basel II. Their model suggests that low risk, small businesses benefit by obtaining loans from banks adopting the IRB approach, while high-risk firms would benefit by obtaining loans from banks that do not adopt this advanced approach. However, their model also predicts that banks will maintain the minimum capital requirement without holding excess capital. This is important because the degree to which banks adjust their levels of capital impacts the total cost of capital. Any competitive advantage achieved by banks adopting the A-IRB approach depends critically on the amount capital ratios fall relative to the reduction in required capital, as noted by Berger (2004). A theoretical model developed by Allen, Caaretti, and Marquez (2006) suggests that minimum capital requirements are not binding constraints.

\section{Relationship Versus Transaction-Based Lending}

Small businesses in the United States typically depend on financial institutions for their funding: i.e., Petersen and Rajan (1994) and Berger and Udell (1995). The importance of the bank is particularly significant for the types of small businesses that are the focus of this paper, such as those small businesses with no access to the capital markets. The literature identifies transaction and relationship-based lending as the two basic approaches that banks select for purposes of lending to small businesses. Boot and Thakor (2000) had argued that the degree to which banks engage in relationship lending relative to transaction lending is a function of technology, competition, and regulation, among other factors. We further the discussion by investigating the dynamics of lending to small businesses, as well as the impact of changes in regulation on the competitive pricing of relational and transactional loans.

\subsection{Information Asymmetries}

Informational asymmetries provide the basis for several theories of financial intermediation, whereby banks are at a competitive advantage to other lenders in the development of information about borrowers as in Diamond $(1984,1991)$ and 
Ramakrishnan and Thakor (1984). This information asymmetry is used to further motivate the development of models with regard to relationship lending and loan pricing.

Sharpe (1990) had highlighted that informational asymmetry arises between banks. In contrast with the current paper, he had assumed that the borrower quality remains constant. We allow the signal to change over time in the lending process as a function of the outcomes from earlier time periods. Our analytical construct to do this is similar to Diamond (1991), but differs significantly in the issues addressed. He had focused on borrower choices and classes of credit that encompass many borrowers, whereas we aim to focus on bank alternatives, providing individual credit scores for each firm.

\subsection{Loan Pricing}

There have been numerous contributions regarding loan pricing for small business loans within the context of relationship lending. Some models predict that the loan interest rate will decline over the duration of the banking relationship. In an examination of the long-term role of collateral, Boot and Thakor (1994) had presented a model of optimal contracting, where subsequent to borrower project success, the firm enjoys an unsecured, below market rate in every subsequent period. However, an interesting aspect of this model is that the results do not depend on learning. Petersen and Rajan (1995) had analyzed loan pricing for small businesses in competitive markets relative to concentrated markets where banks have market power. They had found that market power allows banks to engage in the intertemporal smoothing of rates charged to firms. As a result, although their model predicts that interest rates decline as firms age while the uncertainty regarding the firm is resolved, this decline is faster in competitive markets than in concentrated markets. These models and results are grounded in contracting theory.

Other models predict that interest rates increase over time. Within these models, banks subsidize borrowers in the early years only to extract information rents in later years. Accordingly, Sharpe (1990) had presented a theory of informational asymmetry suggesting that banks exhibit an ex-post monopoly power, despite the fact that they are ex-ante competitive. Banks can use informational advantages to extract rents. Greenbaum, Kanatas, and Venezia (1989) had offered a unique model that is motivated by the bank's need to predict loan demand for funding purposes rather than on the creditworthiness of the borrower.

The conflicting results likely reflect the difficulty with incorporating the complexities of the lender borrower relationship in a theoretical model. The credit quality of the borrower changes over the duration of the relationship, which may lead to changes in loan rates charged to small business customers. Our model predicts that rates will increase or decrease as a function of both bank costs (monitoring) and the credit quality of the borrower.

\subsection{Loan Value}

Rajan (1992) had offered a model where the borrower is influenced to continue by the bank; because of anticipated returns, the borrower exerts more or less effort in 
achieving success in the project examined. Our paper differs significantly from Rajan (1992) in that we assume the quality of the borrower drives the pricing of the loan, since transactional lenders cannot anticipate the outcome of a specific project. Additionally, rather than assuming differential or optimal levels of effort for the borrower, we examine levels of investment that the bank can make in the relationship, leading to improved probabilities of success for the firm.

We also assume that there is an added value to relationship lending that is achieved through monitoring. We use the Boot and Thakor (2000) definition of a relationship loan as one that permits the bank to use its expertise in improving the borrower's project payoff. Monitoring in our model encapsulates all aspects of relationship development and maintenance. Whereas previous models incorporate a cost for monitoring, they fail to incorporate a value for monitoring. We include a variable that is representative of the highly correlated nature between the likelihood of success in the borrower's project vis-a-vis to the likelihood of loan repayment for the bank.

According to Diamond (1996), the value of monitoring to the bank is the expected savings in financial distress costs. The bank can use the threat of liquidation to obtain as much as possible in repayment from the borrower. This value can be added through a change in firm behavior (reduced moral hazard) or the informal feedback mechanism provided by a banker with expertise in the industry. The level of monitoring can be optimized to maximize the bank's return, trading off additional costs in originating the loan relative to increasing the anticipated return. In a recent survey conducted on behalf of the Small Business Administration, Cowan and Cowan (2006) had found that a significant number of banks that lend to small businesses continue to rely exclusively on traditional relationship lending. There is an anecdotal evidence available in the industry that some banks that have gone to transactional lending have reverted to relational lending for small business, both to reduce risk and to increase returns to the institution.

\subsection{Bank Competition}

Boot and Thakor (2000) had presented a model of bank competition, which serves as a suggestive framework for relationship lending in light of increased bank competition within the capital markets. We build on the work of Boot and Thakor (2000) in that we assume banks are not limited in their lending strategy. However, our paper differs from Boot and Thakor (2000) in several important ways. We do not examine the impact of competition from the capital markets. As noted above, small businesses do not have access to the capital markets, and thus, banks competing for this line of business compete exclusively with other financial intermediaries. We also allow for relationship and transaction aspects to influence the same borrower, whereas Boot and Thakor (2000) had assumed that an individual loan is either solely transaction or relationship based. When competition is limited to inter-bank competition in their model, it leads to the increased importance of relationship lending to banks, but with a reduction in the added value of each loan.

Because we integrate the quality of the borrower into our model, we find that the value of the relationship to both the bank and to the borrower increases inversely 
with the quality of the borrower. There seemingly is no incentive for relationship lending to higher credit quality borrowers, although this is only true for one time period. Over multiple time periods, there can be a value of relationship lending to most higher credit quality borrowers. It would only be those borrowers with extremely high credit quality who would not be a target for relationship bankers. Thus, we provide an important, new result contrary to what has been published thus far in the literature by incorporating changes in the quality of the borrower over time.

We propose a model in which banks start with specific information about firms. Over any given period of time, banks tend to "learn" as information changes or becomes readily available, while the quality of firms fluctuates over time as reward or punishment for good or bad decisions. A key result of our research is that there is a role for relationship banking even in the absence of informational asymmetries between competitors.

\subsection{BASEL II}

We also extend the literature by incorporating relationship and transaction based lending aspects when analyzing the potential impact of Basel II. Consistent with Repullo and Suarez (2004), we assume that banks take advantage of potential capital reductions. However, we do not require that banks hold minimum capital, but simply that they take advantage of reductions available from Basel II relative to their current levels of capital. We go beyond Repullo and Suarez (2004) by extending beyond the limits of two risk categories to multiple categories of risk that is consistent with practice. However, the focus of Repullo and Suarez (2004) with that of this paper are quite different. This paper focuses on the impact of dynamic changes in credit quality in which implications for Basel II are secondary, but important. In contrast, Repullo and Suarez (2004) had focused on loan pricing changes in the limited context of the impact of the changes from Basel I to Basel II. Therefore, the impact of regulatory change was the primary focus of that paper.

\section{The Model}

\subsection{General Framework}

The participants in the model are commercial banks, borrowers, and depositors. Commercial banks invest in illiquid, small business loans. We follow Boot and Thakor's (2000) definition of a relationship loan whereby the bank has the potential to improve the borrower's project payoff. A choice parameter designates how banks elect the degree of investment in relationship lending. Whereas Boot and Thakor (2000) had allowed banks to participate in the project payoff through an investment in specialization, we simply allow banks to invest in monitoring without making it more specific to the choice of industries. Our model improves the likelihood of repayment, but the project payoff goes solely to the small business.

There is a limited amount of historical information available for these firms that makes underwriting difficult. The firms of course, are constrained in raising capital due to size limitation. We exclude from consideration those high growth 
firms that seek equity financing, such as venture capital for early business phases, rather focusing on those loans obtained from financial institutions.

In this paper, we examine the differential impact of lending strategies based on firm quality; the benefits of monitoring; and the differing costs among banks associated with obtaining information. There is a very significant difference in our results from those of earlier authors. With small businesses, the bank is learning about the quality of the borrower rather than assessing only the quality of the project. Earlier papers hypothesize a quality rating for a "project". In transactional lending, the lender only obtains a quality score for the borrower without a detailed investigation of the project. The relational lender for a small business loan similarly finds out about the quality of the borrower and may not examine the quality of the project as closely at the beginning of the project.

\subsection{Model Details}

Consider an economy in which firms are endowed with a project and seek external financing from a bank. A firm shops multiple banks in the initial time period, both transactional and relational. Relationship loans are those in which the bank can affect the project payoff of the borrower. In contrast, transaction lending is a pure funding transaction in which the project payoff is unaffected by the bank's involvement.

Two types of financial intermediaries can facilitate the financing of the projects: those banks that use credit scoring only and those that use relationship banking only. Many banks use both approaches and can decide to pursue a transactional or relationship strategy on a firm-by-firm basis. For these banks, the bank chooses only the strategy that benefits the bank. From the perspective of the borrower, the borrower sees only one rate and arrangement offered. The loan is either transactional or relational, and will differ in implementation because of different monitoring requirements. All banks are perfectly competitive ex-ante; thus, we ignore intertemporal discounting. For small businesses, banks have only two methods to evaluate the quality of a firm: a credit score or underwriting. Banks observe the credit quality measure prior to making a loan.

Relationship lenders collect information on a firm in a traditional manner for the purposes of underwriting the loan. In time period 0 , a bank starts by collecting information on a firm and on the principals in the firm. The bank calculates an internal score for a firm and uses this information to make the lending decision. Relationship lending involves a monitoring cost that declines over the length of the relationship.

Transactional lenders use credit scores to make lending decisions. With credit scoring, there are two possibilities for rating the quality of a business. One is for a bank to use the score purchased from a credit bureau. Banks with limited resources may not have the ability to customize the information they receive, but still may benefit from the use of a credit score that is indicative of a small business. Another possibility is to combine the credit score with the internal score as part of a customized scoring system tuned to the particular population of firms that the bank considers as its customer base. 
Due to the nature of credit scoring, all transactional lenders purchase exactly the same credit score for a particular firm. When determining the quality of the borrower, underwriters use the same information, so the relational score computed by a relational bank is assumed to be the same as the credit score. This is somewhat of a restrictive assumption, as it does not allow for noise in the system (to relax this assumption, we would have to model how noise in the system introduces a new source of risk for the banks, both systemic and random). This is beyond the scope of the current paper, but raises interesting questions for the future.

\subsection{Information Observed Over Time}

We assume that during time period $t$, the quality of a firm, $f$, is observed as $\theta_{\mathrm{f}, \mathrm{t}^{\circ}}$ The quality measure is a value with a range $[0,1]$, characteristic of an individual firm. For all firms, the distribution of quality scores is $F(\theta)$. When considering the initial quality of a firm, a small business does not spring into life. Rather, it is the culmination of preparatory work and operations funded through private sources. Time zero is the first time that a small business seeks outside funding. How well a firm has prepared until this time determines the quality measure for the firm at time zero, $\theta_{\mathrm{f}, 0}$.

A firm's quality changes according to its performance over time, depending upon the success or failure of projects. A successful project builds up the firm; an unsuccessful one weakens the firm. A series of unsuccessful projects weakens the firm to the point where it can no longer borrow and must go out of business. The quality of a firm at time $t$ is a function of its quality in time $t-1$ and the $+/$ - change as the firm signals success or failure. In general, the firm's quality changes as:

$\theta_{\mathrm{f}, \mathrm{t}+1}=\mathrm{H}\left(\theta_{\mathrm{f}, \mathrm{t}} \pm\right)$

The only requirement on $\mathrm{H}(\mathrm{o})$ is that $\theta_{\mathrm{f}, \mathrm{t+1}}>\theta_{\mathrm{f}, \mathrm{t}}$ if the project is a success, $\theta_{\mathrm{f}, \mathrm{t}+1}<$ $\theta_{\mathrm{f}, \mathrm{t}}$ if the project is a failure, and $\mathrm{H}(\mathrm{o})$ is monotonic and invertible. We assume that an outcome at $t$ is independent of outcomes in previous time periods.

Quality measures from third parties or computed by banks are assumed to range along a fixed range that can be transformed linearly to the $[0,1]$ range, preserving the relative variability and shape of the distribution of predictions. Transformed, these quality measures become comparable scores sold by a credit bureau or created by a bank that engages in relational lending.

\subsection{Costs of Obtaining Information}

Costs associated with each method of obtaining a score differ. For transactional lenders, bureau-based scores are relatively inexpensive, with some minor fixed costs associated with collecting information for purposes of due diligence. There are no ongoing costs such as monitoring. This means that the bank abandons having an impact on the success of a project and that the cost of obtaining information about a firm recurs every time the firm applies for a loan. This cost is $\mathrm{C}_{\mathrm{T}}=\mathrm{T}$ for all $t$, where 
$T$ is the cost of generating an account that includes the cost of obtaining the credit score.

For a relational bank, there is a similar cost of initial information plus a cost of monitoring the relationship. The greater there is an investment in monitoring, the greater the likelihood of a repayment. Over time, as the lender gathers more information and more knowledge about a firm, the monitoring costs decline asymptotically to a lower bound. If the relationship is interrupted, the cost of obtaining initial information recurs. The cost of establishing a relationship to collect information in determining the viability of a project with an ongoing cost of monitoring is $C_{R, t}=m_{t}$. The value $m_{t}$ declines over time, $\partial m_{t} / \partial t<0$, but the decline lessens in each subsequent time period so that $\partial^{2} \mathrm{~m}_{\mathrm{t}} / \partial \mathrm{t}^{2}<0$. A function of the initial expenditure $m_{0}$ is $m_{t}$ where relational costs are greater than transactional costs for earlier time periods, but can be less than transactional costs at later time periods if the borrower stays with the same lender for a sufficiently longer period of time.

In summary,

$\mathrm{C}_{\mathrm{T}}=\mathrm{T}$ and $\mathrm{C}_{\mathrm{R}, \mathrm{t}}=\mathrm{m}_{\mathrm{t}}$

\subsection{Probabilities of Success and Recovery}

The quality score is an indicator of repayment. With a suitable transformation, any credit score can be transformed to be on the range [0,1]. Without loss of generality, we use the quality score as a probability of repayment.

Information regarding a business's successes and how likely it is to repay is captured in the credit score that a bank purchases from a credit bureau. Since this is what a credit bureau provides, why would a bank take on the greater cost of developing and maintaining a relationship with a small business? The answer would appear to be in the tradeoff between the costs of monitoring versus the improved likelihood of repayment.

The likelihood of repayment can be improved through monitoring in relational loans. As had Boot and Thakor (2000), we too had modified the likelihood of repayment by increasing the likelihood of project success. With monitoring, the likelihood of repayment becomes

$\mathrm{P}_{\mathrm{f}, \mathrm{t}}=\theta_{\mathrm{f}, \mathrm{t}}+\gamma\left[\mathrm{m}_{0}\right] *\left(1-\theta_{\mathrm{f}, \mathrm{t}}\right)$

where $\mathrm{P}_{\mathrm{f}, \mathrm{t}}$ is the likelihood of success of the project (and repayment of the loan), and $\gamma\left[\mathrm{m}_{0}\right]$ is a factor, denoting the proportion of the likelihood of failure that will be converted to an additional likelihood of success, as a result of monitoring.

The proportion of increase in equation (2) is denoted as $\gamma\left[\mathrm{m}_{0}\right]$. This factor is a function only of $\mathrm{m}_{0}$, the amount spent by the lender on monitoring in the first period when the loan is initiated. Economies of scale realized, $m_{t}$ declines uniformly, but $\gamma\left[\mathrm{m}_{0}\right]$ remains constant even though spending goes down. If this were not the case, then the value of monitoring would decline over time, even though the 
lender is learning more about the borrower in each subsequent period. We require that $0<\gamma\left[\mathrm{m}_{0}\right]<1$, and diminishing returns as an expenditure increases, or $\partial \gamma / \partial \mathrm{m}_{0}>0$, $\partial^{2} \gamma / \partial \mathrm{m}_{0}^{2}<0$. For the remainder of this paper, the terms $\gamma\left[\mathrm{m}_{0}\right]$ and $\gamma$ are synonymous with one another.

\subsection{Pricing of Loans}

Boot and Thakor (1994) have a pricing model for collateralized lending, but they present a pricing model for business loans with no recovery if the loan defaults. Sharpe (1990) has a similar model with no provision for collateral, and the probability of repayment is a function of the success of the project, not of the firm. Many small business loans are collateralized or guaranteed by owners. Berger and Udell (1996) had found that small business loans administered by large banking organizations tend to have collateral pledged less often than banks with assets less than $\$ 1$ billion. We develop a pricing model that incorporates a recovery if the loan defaults.

We assume that the borrower takes a $\$ \mathrm{~L}$ loan to invest for one time period. If the project is successful, the project yields $\$ \mathrm{~L} * \Psi$ to the borrower. The probability of repayment is a function of the quality of the borrower and the degree of monitoring of the project. The bank's zero excess profit loan rate is established by setting the bank's gross cost of funds to the gross expected return on the loan, as shown in the following:

$$
\left(1+\mathrm{r}_{\mathrm{m}}\right) \mathrm{L}+\mathrm{C}_{\mathrm{j}, \mathrm{t}}=\mathrm{P}_{\mathrm{f}, \mathrm{t}} *\left(1+\mathrm{r}_{\mathrm{c}, \mathrm{t}}\right) \mathrm{L}+\left(1-\mathrm{P}_{\mathrm{f}, \mathrm{t}}\right) * \beta * \mathrm{R}
$$

where

$\begin{array}{ll}\mathrm{r}_{\mathrm{m}} & =\text { the cost of funds, } \\ \mathrm{r}_{\mathrm{c}, \mathrm{t}} & =\text { the rate charged by lender type } \mathrm{c} \text { at time } \mathrm{t}, \\ \mathrm{L} & =\text { the amount loaned, } \\ \beta & =\text { the recovery rate for the collateral } \mathrm{R}, \\ \mathrm{P}_{\mathrm{f}, \mathrm{t}}=\theta_{\mathrm{f}, \mathrm{t}}+\gamma\left[\mathrm{m}_{0}\right] *\left(1-\theta_{\mathrm{f}, \mathrm{t}}\right) & =\text { the probability of repayment, and } \\ \gamma\left[\mathrm{m}_{0}\right] \equiv 0 & =\text { for transactional lenders. }\end{array}$

The rate that would be charged to the borrower from loan source $j$ at time $t$ is then:

$$
r_{c, t}=\frac{r_{m}+\frac{C_{j, t}}{L}+\left(1-p_{f, t}\right)\left(1-\beta \frac{R}{L}\right)}{p_{f, t}}
$$

This rate has three components: the cost of funds rate; the per dollar cost of originating \& monitoring the loan; and the loss if collateral recovery doesn't fully cover the loan amount. These components relate to the final rate charged to the borrower in several ways. The rate to the borrower increases if either the cost of funds to the bank increases or the cost of originating and monitoring the loan increases. Conversely, the rate to the borrower decreases if the recovery rate on the collateral increases or the likelihood of the project success increases. Note that 
$\mathrm{r}_{\mathrm{T}, \mathrm{k}}$ for transactional lenders is the same for all $k$ for fixed credit quality, so for the remainder of this description $\mathrm{r}_{\mathrm{T}, \mathrm{k}}=\mathrm{r}_{\mathrm{T}}$ for all $k$. Similarly, $\mathrm{r}_{\mathrm{C}, \mathrm{k}}$ is for relational lenders. Since the $\mathrm{r}_{\mathrm{T}, \mathrm{k}}$ are all identified as constant and subscripted by " $T$ ", for the remainder of this description, $r_{C, k}=r_{k}$ will be used. The numeric subscript will always be for relational lenders, while the letter subscript " $T$ " will always be for transactional lenders.

We will now investigate the differences between transactional and relational lenders that involve initial lending to a firm, lending to a firm after the initial relationship is established, and strategies for profit maximization by the banks.

\section{Basic Findings and Relationships at Each Point in Time}

This paper focuses on dynamic change. We need to derive some basic results for each time period. Using these relationships, we can then examine long-term versus short-term decision-making.

Remember that relationship and transactional lenders observe the same measure of credit quality. The relationship bank offers a different rate than the transaction bank because the costs of lending differ between the two; resultant being that the relational bank offers a greater likelihood of success to the firm (services offered by the relational lender improve the probability of a borrower's success, so it offers a loan rate commensurate with the improved likelihood of success). In this section, we summarize relationships and show that it is possible for both the borrower and the relational lender to maximize returns.

\subsection{Borrower's Choice}

The borrower will only see the two rates (relational and transactional) being offered by the banks. No borrower will be willing to borrow if the rate being charged is greater than the rate of return that the borrower expects to achieve, denoted as $\Psi$. Assuming both loan rates are less than $\Psi$, the borrower chooses the loan with the greater expected payoff.

The expected payoff to the borrower is the likelihood of success multiplied by the net return:

$\left.\left\lfloor\theta_{\mathrm{f}, \mathrm{t}}+\gamma\left[\mathrm{m}_{0}\right]^{*}\left(1-\theta_{\mathrm{f}, \mathrm{t}}\right)\right]^{*}(1+\Psi)-\left(1+\mathrm{r}_{\mathrm{R}, \mathrm{t}}\right)\right]^{*} \mathrm{~L} \quad$ for a relational loan (6)

$\left\lfloor\theta_{\mathrm{f}, \mathrm{t}}\right\rfloor *\left[(1+\Psi)-\left(1+\mathrm{r}_{\mathrm{T}}\right)\right] * \mathrm{~L} \quad$ for a transactional loan $(7)$

The net return to the borrower is greater for a relational loan than for a transactional loan if improvement in the likelihood of success is sufficiently enhanced. Even though the borrower is paying more for the loan, the net return will be greater if the probability of success sufficiently increases. This is true for all borrowers with credit scores less than $\theta \mathrm{u}, \mathrm{t}$ : 
Figure 1: Minimum Acceptable Quality Score for the Borrower Who Expects to Achieve at Least an 8\% Rate of Return and Quality Score Breakeven for Choice Between Relational and Transactional Lender

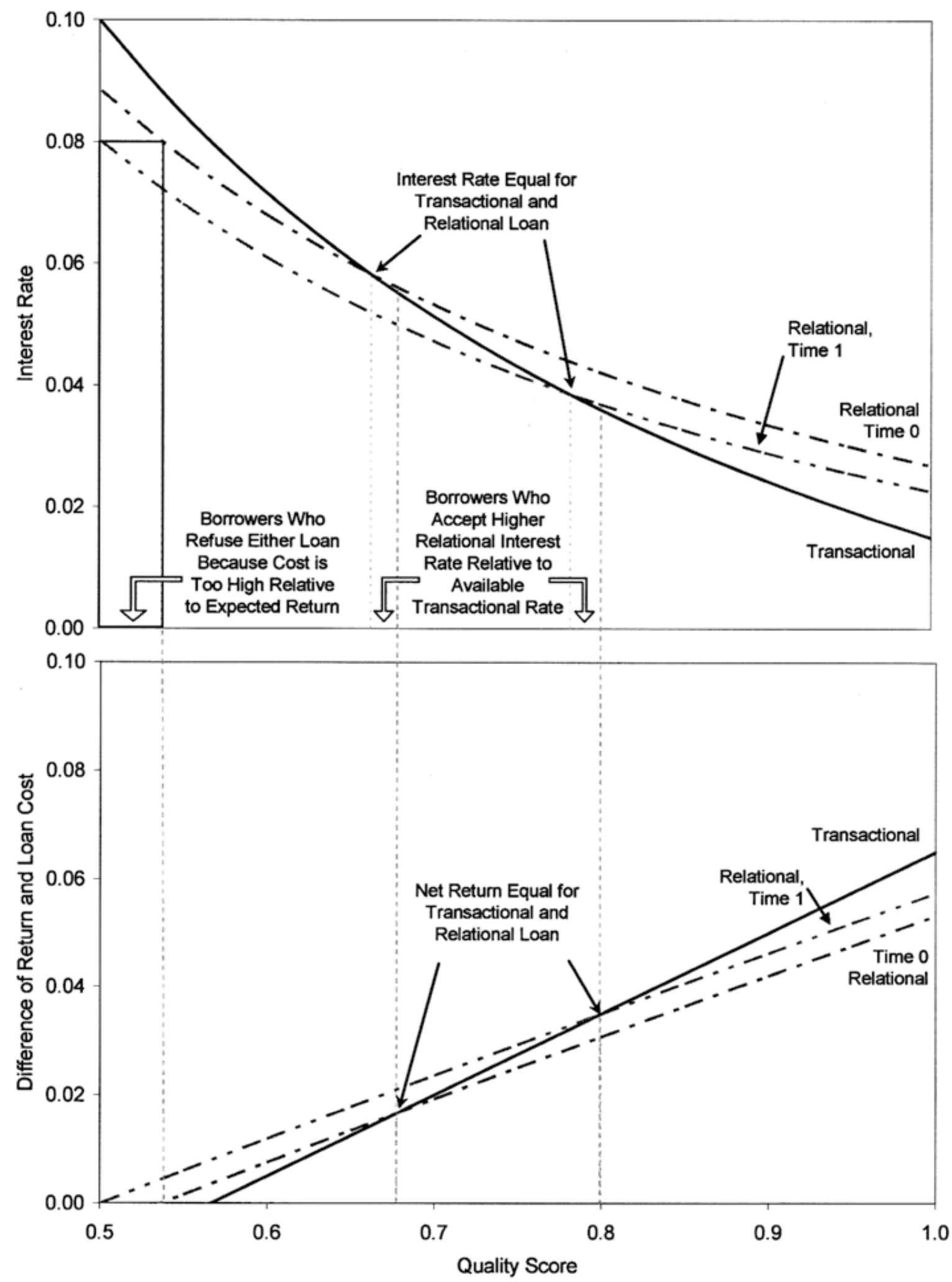


$\theta_{U, t}=1-\frac{J_{t}}{\gamma\left[m_{0}\right]}$, where $J_{t}=\frac{\left[r_{m}+\frac{m_{t}}{L}+\left(1-\beta \frac{R}{L}\right)\right]-\left[r_{m}+\frac{T}{L}+\left(1-\beta \frac{R}{L}\right)\right]}{\left[\Psi+\left(1-\beta \frac{R}{L}\right)\right]}$

A borrower with a credit score less than $\theta_{\mathrm{U}, \mathrm{t}}$ will choose the relational rate over the transactional rate, even if the relational rate is higher because the relation improves the likelihood of a positive net return (see Figure 1). This calculation is repeated for each time period for declining monitoring costs. There will be a sequence of values, $\theta_{\mathrm{U}, 0}<\theta_{\mathrm{U}, 1}<\theta_{\mathrm{U}, 2}<\ldots$ where later values of $\theta_{\mathrm{U}, \mathrm{t}}$ are increasing because costs are declining.

A similar sequence arises for borrowers if they do not expect to achieve a rate of return $\Psi$ greater than the value of the loan. For a transactional loan, this means that $\Psi$ must be greater than $\mathrm{r}_{\mathrm{T}, \mathrm{t}^{\circ}}$. For a relational loan, $\Psi$ must be greater than $\mathrm{r}_{\mathrm{R}, \mathrm{t}}$, which occurs at

$$
\theta_{\mathrm{L}, \mathrm{t}}=\frac{\mathrm{r}_{\mathrm{m}}+\frac{\mathrm{m}_{\mathrm{t}}}{\mathrm{L}}+\beta \frac{\mathrm{R}}{\mathrm{L}}-\gamma\left(\Psi+\beta \frac{\mathrm{R}}{\mathrm{L}}\right)}{(1-\gamma)\left(\Psi+\beta \frac{\mathrm{R}}{\mathrm{L}}\right)}
$$

For first-time borrowers with credit quality below $\theta_{\mathrm{L}, 0}$ cannot afford to take on the loan since the project return won't cover the expense of the loan. As stated above, there will be a sequence of values, $\theta_{\mathrm{L}, 0}<\theta_{\mathrm{L}, 1}<\theta_{\mathrm{L}, 2}<\ldots$ where later values of $\theta_{\mathrm{L}, 0}$ are decreasing because costs are declining.

If the rate on the loan exceeds the expected rate of return, no borrower will accept a loan, meaning that there is a minimum quality score needed for borrowers to accept a loan that they can afford. Similarly, for a single point in time, there is a unique breakeven point where the value of a loan is the same for the borrower who can choose between a transactional and relational lender.

\subsection{Profit Maximization for Relational Bankers Attracting New Borrowers}

The relational banker has an opportunity to maximize his return, both by improving the probability of success to his borrowers and also by taking business away from the transactional banker. The increased investment in monitoring leads to improving the likelihood of success with diminishing returns as the expenditure increases. However, interest rates offered by the relational banker also increase as the cost of monitoring increases. There is a gain at the upper and lower end of the range where the relational banker has an advantage as the improvement in the probability of repayment improves, but there is also a loss at each end as the interest rate increases. The greatest return for relational lenders comes from balancing gains and losses in market share with expected returns for individual borrowers.

We define $\Gamma_{0}$ as the expected return for the relational banker from the first loans made. We integrate over the range where borrowers will accept a relational loan. For successful projects, the return to the bank is $1+r_{R, 0}$. For projects that do not succeed, the bank recovers some fraction $(\beta)$ of the collateral as a proportion of the loan value. 
$\Gamma_{0}=\int_{\theta_{\mathrm{L}, 0}}^{{ }^{\theta} \mathrm{U}, 0} \mathrm{f}(\theta)\left[\{\theta+\gamma(1-\theta)\}\left(1+\mathrm{r}_{\mathrm{R}, 0}\right)+(1-\gamma)\{1-\theta\}\left(\beta \frac{\mathrm{R}}{\mathrm{L}}\right)\right] \mathrm{d} \theta$

where

$\theta_{\mathrm{U}, 0} \quad=$ was defined as the highest quality score for which a borrower would accept a relational loan,

above $\theta_{\mathrm{U}, 0}=$ the borrower would take a transactional loan,

$\theta_{\mathrm{L}, 0} \quad=$ the lowest quality score for which a borrower would accept a relational loan:

$\theta_{\mathrm{U}, \mathrm{t}}=1-\frac{1}{\gamma} \frac{\frac{\mathrm{m}_{\mathrm{t}}}{\mathrm{L}}-\frac{\mathrm{T}}{\mathrm{L}}}{\Psi+\beta \frac{\mathrm{R}}{\mathrm{L}}}$

$\theta_{\mathrm{L}, \mathrm{t}}=\frac{\mathrm{r}_{\mathrm{m}}+\frac{\mathrm{m}_{\mathrm{t}}}{\mathrm{L}}+\beta \frac{\mathrm{R}}{\mathrm{L}}-\gamma\left(\Psi+\beta \frac{\mathrm{R}}{\mathrm{L}}\right)}{(1-\gamma)\left(\Psi+\beta \frac{\mathrm{R}}{\mathrm{L}}\right)}$

Note: $\quad \theta_{\mathrm{U}, \mathrm{t}}>\theta_{\mathrm{L}, \mathrm{t}}$

$$
\gamma>\frac{\frac{\mathrm{m}_{\mathrm{t}}}{\mathrm{L}}-\frac{\mathrm{T}}{\mathrm{L}}}{\Psi-\left(\mathrm{r}_{\mathrm{m}}+\frac{\mathrm{T}}{\mathrm{L}}\right)}
$$

In other words, the gain offered by the bank has to be greater than the increase in cost to the borrower relative to his net return when borrowing from a transactional lender.

The relational banker can control the level of investment made, $\mathrm{m}_{0}$, in monitoring the loan. The expected return can be maximized by taking the derivative of $\Gamma$ with respect to the initial investment. For a single time period, we have the following:

$\frac{\partial \Gamma_{0}}{\partial \mathrm{m}_{0}}=\frac{1}{\mathrm{~L}}\left[\mathrm{~F}\left(\theta_{\mathrm{U}, 0}\right)-\mathrm{F}\left(\theta_{\mathrm{L}, 0}\right)\right]+\left\{1+\mathrm{r}_{\mathrm{m}}+\frac{\mathrm{m}_{0}}{\mathrm{~L}}\right\}\left[\mathrm{f}\left(\theta_{\mathrm{U}, 0}\right) \frac{\partial \theta_{\mathrm{U}, 0}}{\partial \mathrm{m}_{0}}-\mathrm{f}\left(\theta_{\mathrm{L}, 0}\right) \frac{\partial \theta_{\mathrm{L}, 0}}{\partial \mathrm{m}_{0}}\right]$

with $\frac{\partial \theta_{\mathrm{U}, 0}}{\partial \mathrm{m}_{0}}=\frac{\frac{\partial \gamma}{\partial \mathrm{m}_{0}}\left(\frac{\mathrm{m}_{0}}{\mathrm{~L}}-\frac{\mathrm{T}}{\mathrm{L}}\right)-\frac{\theta}{\mathrm{L}}}{\gamma^{2}\left(\Psi+\beta \frac{\mathrm{R}}{\mathrm{T}}\right)}$ and $\frac{\partial \theta_{\mathrm{L}, 0}}{\partial \mathrm{m}_{0}}=\frac{\frac{\partial \gamma}{\partial \mathrm{m}_{0}}\left(\mathrm{r}_{\mathrm{m}}+\frac{\mathrm{m}_{0}}{\mathrm{~L}}-\Psi\right)+\frac{1-\gamma}{\mathrm{L}}}{(1-\gamma)^{2}\left(\Psi+\beta \frac{\mathrm{R}}{\mathrm{r}}\right)}$

Setting the above equation (11) equal to zero and solving for $\mathrm{m}_{0}$ gives us the investment that the relational bank can make while maximizing its return. Unless the density at $\theta_{\mathrm{L}, 0}$ is significantly less than the density at $\theta_{\mathrm{U}, 0}$, we would expect that the second term in (11) to be negative; thus, we can find a positive $\mathrm{m}_{0}$ that satisfies the required conditions, but only for one period.

\section{Excess Profits from Retained Borrowers}

In this section and the next, we present three key ways in which a relational lender can realize excess or additional profits. In some instances, these gains come from adding borrowers that the lender might not have otherwise taken on. In other 
instances, these gains come from being able to charge more for services because of a temporary, dominant position.

Having considered how long a borrower will stay with a lender, we now consider how the relational lender can increase his profits through this longer-term relationship. In Section 5 we considered only those normal profits that would be obtained by optimizing an investment in one time period. For a constant return per dollar loaned, the more loans made the better if they could be taken away from the transactional lenders. But these profits reflect only the transfer of profits that would occur from a transactional to relational lender. Once a relational lender has a relationship, it is also possible to accrue monopoly profits over time.

\subsection{Acquired and Retained Borrowers}

A transactional borrower who fails on a project may be better off with a relational loan in a subsequent time period. This is easily seen in Figure 2 where the borrower who fails on their first project has a decline in their credit score (the failure uses resources which leads to a decline in borrower quality). Thus, some borrowers who were transactional borrowers will become relational in subsequent time periods.

Conversely, a successful relational borrower may have a sufficient increase in quality to find that he would have been better off with a transactional loan, but will stay with the relational lender if the cost reduction for the transactional loan is less than the decline in cost in the relational loan. This is seen in Figure 3, where the borrower's quality increase would lead them to consider a transactional loan, but the decline in the cost of a second relational loan (because the monitoring costs decline) leads the borrower to stay with the relationship.

If the borrower fails in the first project, at a future time period, the quality of the borrower is diminished. Some borrowers who had a sufficiently high quality to obtain a low rate, transactional loan might suffer a decline of quality after a failure that would require them to seek a relational loan because the relational loan may now have a relative pricing advantage.

If the borrower succeeds on the first project, at the next time period, the quality of the borrower is improved. Some borrowers who had obtained a relational loan will now have a better quality. However, the relational cost for monitoring will decline. As a result, for these borrowers, the relational loan will still be more advantageous.

From equation 1, we have $\theta_{\mathrm{f}, \mathrm{t}+1}=\mathrm{H}\left(\theta_{\mathrm{f}, \mathrm{t}} \pm\right)$. Dropping the notation for the firm, "f", we have simply that for a one period time change that there is an increase (decrease) in the quality score if the firm succeeds (fails). In time period 1, we have $\theta_{1}=\mathrm{H}\left(\theta_{0}\right)$; conversely, we can invert the relationship to find what the score would have been when the borrower first applies for the loan if we know the current quality score: $\mathrm{H}^{-1}\left(\theta_{1}\right)=\theta_{0}$.

Proposition One: Banks making relational loans will capture borrowers who had transactional loans whose credit quality declines, and will retain some of the borrowers who would have improved to a transactional loan because of declining monitoring costs. 
Figure 2: Declining Quality, Transactional Borrowers Who Move to Relational Borrowing

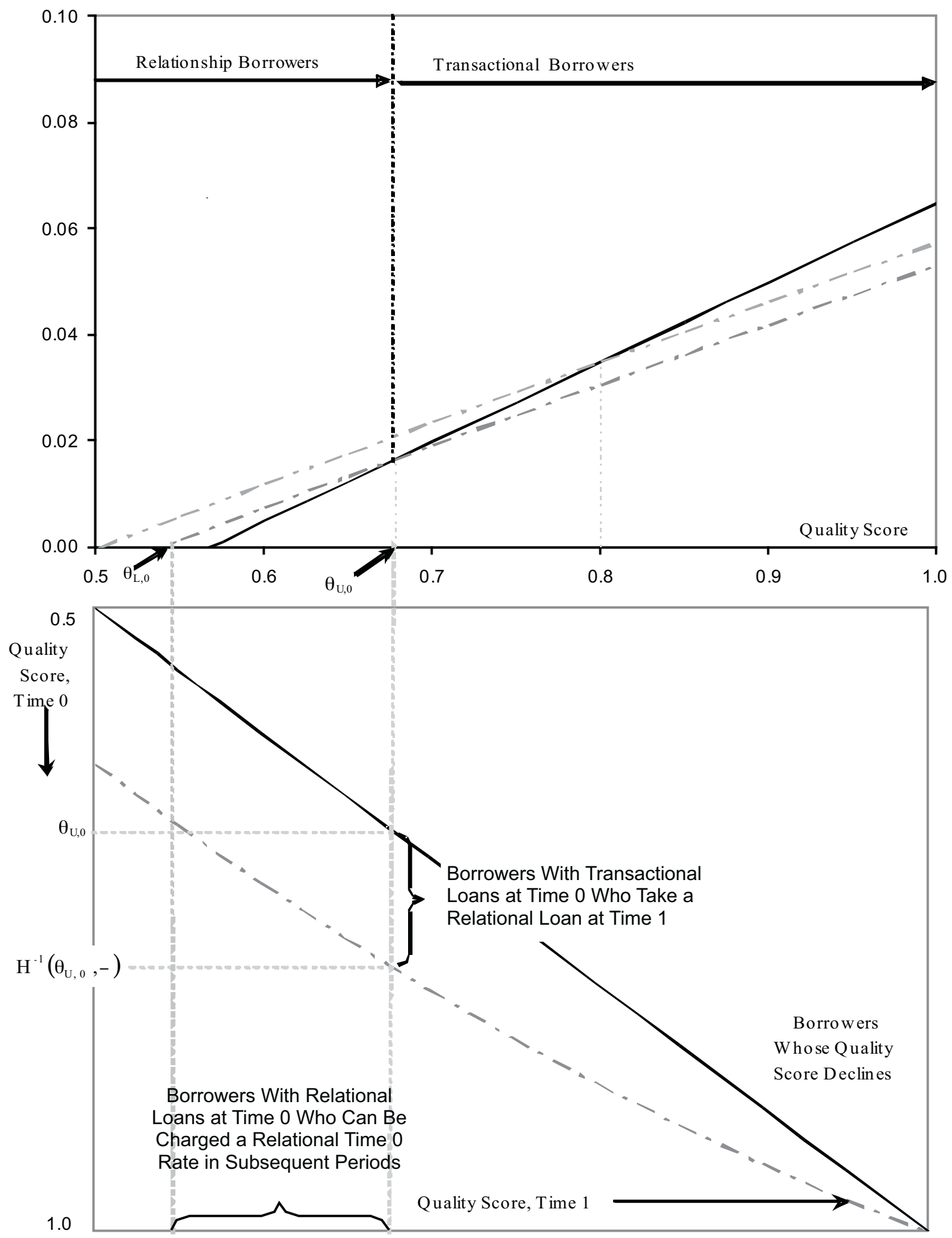


Figure 3: Successful Relational Borrowers Who (Do Not) Move to Transactional Borrowing

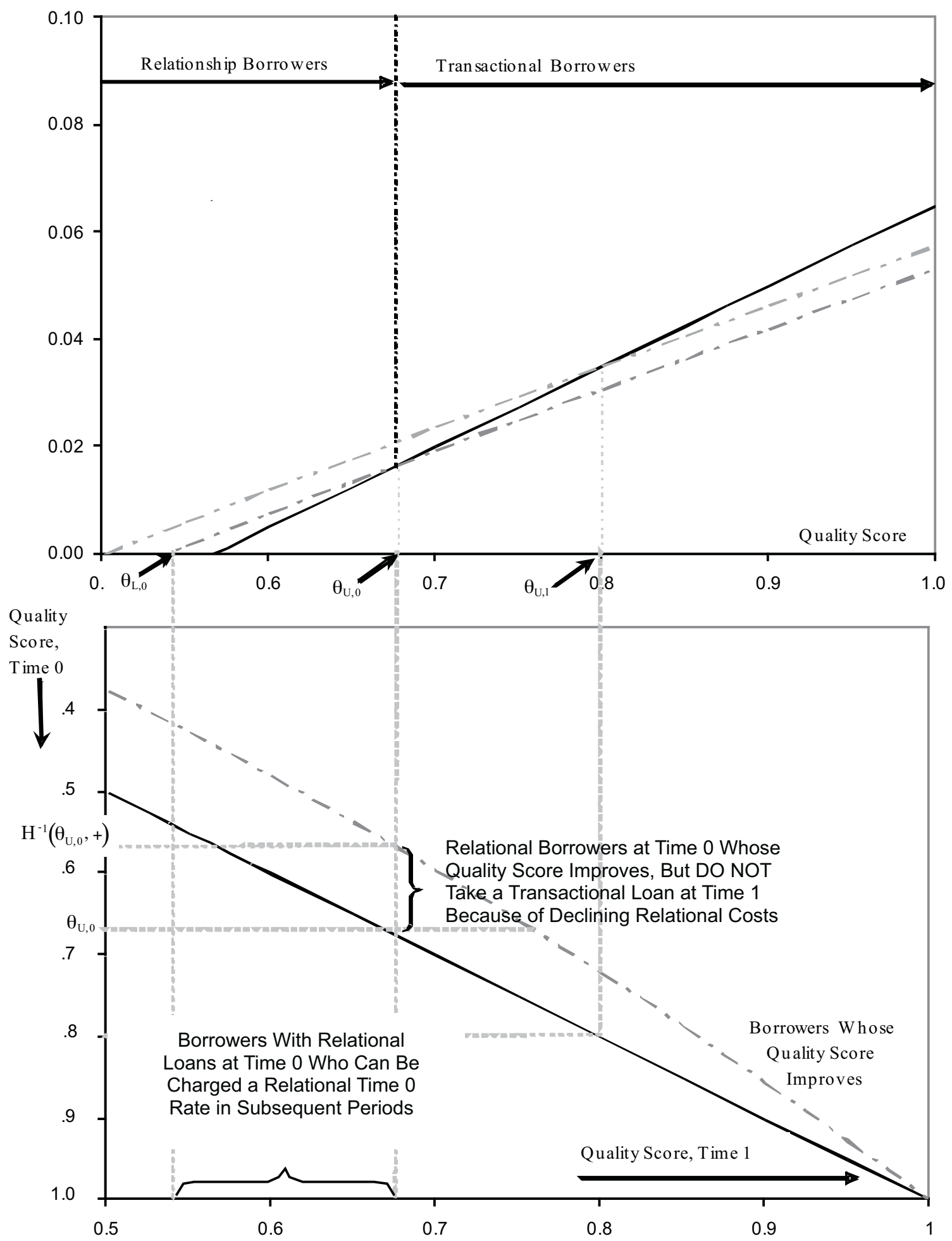


Under the model proposed here, a borrower who fails defaults on their loan, and so they begin the borrowing process anew if they can find a new lender. One can imagine that their quality score would decline (precipitously!) if they default. Consequently, they would need to find new collateral and a new lender to be able to continue any endeavor. The proportion of borrowers that will switch from transactional to relational is:

$$
\begin{aligned}
& \mathrm{H}^{-1}\left(\theta_{\mathrm{U}, 0},-\right) \quad \mathrm{H}^{-1}\left(\theta_{\mathrm{U}, 0},-\right)
\end{aligned}
$$

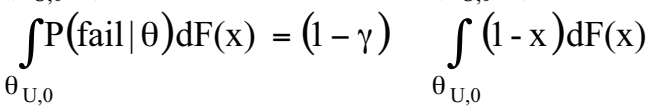

These borrowers, since they were in the position of potentially switching between transactional lenders, will now find it more advantageous to obtain a relational loan (see Figure 2).

The proportion of borrowers that would have switched from relational to transactional, yet won't, due to declining monitoring costs is (see Figure 3):

$$
\int_{\mathrm{H}^{-1}\left(\theta_{\mathrm{U}, 0},+\right)}^{\theta_{\mathrm{U}, 0}} \mathrm{P}(\operatorname{succeed} \mid \theta) \mathrm{dF}(\mathrm{x})=\int_{\mathrm{H}^{-1}\left(\theta_{\mathrm{U}, 0},+\right)}^{\theta_{\mathrm{U}, 0}}(\mathrm{x}+\gamma(1-\mathrm{x})) \mathrm{dF}(\mathrm{x})
$$

\subsection{Additional Profits on Retained Borrowers}

A second result in this section addresses the profitability of the loans for relational lenders. Because of competition, transactional lenders never make more than ordinary profits through profit that is structured into fees (the cost of originating the loan). These are also minimized because of competition with other transactional lenders. The same is true for relational lenders in the initial period since relational lenders compete with one another and with transactional lenders for new business. However, once a relationship is established, competition exists only between the one relational lender who holds the relationship and the transactional lenders. There is an opportunity to realize extra profits from borrowers that relational lenders retain. Relational lenders can charge a higher rate (up to the rate charged in the initial period) for borrowers retained from the initial period.

Borrowers who were successful in the first period have improved quality scores. Some of the borrowers with improved quality scores will not improve sufficiently to attract comparable offers from transactional lenders. Therefore, this subset of borrowers will still only attract relational lenders, and only one relational lender will have a competitive advantage over all the other relational lenders. This one lender can charge any rate up to the rate charged by other relational lenders and make an additional profit on the transaction. If there is a cost to the borrower to shop lenders (the borrowers time to search out a new lender), then the borrower will stay with the same lender and the lender can charge the same rate as in the first loan.

Monopoly profits are calculated as the difference in rates multiplied by the loan amount over the set of relevant quality measures. The profit is the large gap bounded below and above by time 0 and 1 relational curves. On the left $\&$ right, the minimum quality is defined by the borrower's expected rate of return and the breakeven point between relational and transactional lending at time 0 . The expected monopoly profit in time period 1 that can be realized is: 
Proposition Two: Banks can make excess profits on some relational loans because of retention of borrowers whose cost to monitor has declined in subsequent periods.

$$
\text { Additional Profits (P2) }=\int_{\mathrm{H}^{-1}\left(\theta_{\mathrm{L}, 0},+\right)}^{\mathrm{H}^{-1}\left(\theta_{\mathrm{U}, 0},+\right)}\left\{\mathrm{r}\left[\mathrm{H}(\mathrm{x},+) \mid \mathrm{m}_{0}\right]-\mathrm{r}\left[\mathrm{H}(\mathrm{x},+) \mid \mathrm{m}_{1}\right]\right\}(\mathrm{x}+\gamma(1-\mathrm{x})) \mathrm{dF}_{0}(\mathrm{x})
$$

Note that this result is for those borrowers whose project succeeds. If they fail to repay, they're assumed to default, and if they plan to borrow again, they would have to start with a new lender. The same result is seen for those borrowers retained in successive time periods until the borrower defaults or finally transitions to a transactional lender. At each successive time there are fewer borrowers (since some will have defaulted or transitioned), but greater profits are to be had from these borrowers.

However, there are greater monopoly profits that can be gained by considering longer time periods and other strategies that would affect the boundaries given in the above equation (14). The next section addresses possible strategies that would expand the monopoly profits that can be realized over longer time horizons.

\section{More Aggressive Profit Seeking}

Now, we consider the dynamic nature of credit quality and how this dynamism affects borrowers and lenders. The lender has no control over how much of an increase or decrease one observes in the quality of a borrower (other than the assistance given by relational lenders). We assume that it changes exogenously. However, we noted earlier that the relational lender chooses how much of an investment it makes in the improvement of the project's likelihood of success, and the relational lender controls the prices set. The relational lender can also offset first period losses with expected profits in subsequent time periods and take on borrowers that may be profitable only if retained over more than one period. Recognizing that there is a possibility to attain profits even greater than described in the last section, the lender can attempt two strategies that will increase profits.

\subsection{Borrowers Who Otherwise Would Not Obtain a Loan}

Some borrowers cannot obtain a loan as the rate they would be charged would be greater than their anticipated rate of return. These borrowers would be only those with the lowest quality scores. The lender knows that of this set, some borrowers would be successful, and in the next period these borrowers would be charged a substantially lower rate. It may be possible for the bank to make profitable loans to these borrowers (who might otherwise not get a loan) by engaging in tradeoff pricing: lowering the price of the loan to the rate of return in the first period and compensating in the pricing of loans for this group in subsequent periods.

Proposition 3: It is possible for a relational bank to absorb an expected one time loss for low quality borrowers in the initial period and compensate for the loss with 
an expected gain from borrowers in later times for a net gain. To do this, the bank must extend loans below the minimum quality level set down to a new minimum quality level,

Proof: For one time period, a bank's expected net gain is calculated as:

$$
\begin{aligned}
\text { Additional Profits (P3) = } & \int_{\mathrm{H}^{-1}\left(\theta_{\mathrm{L}, \Pi},+\right)}^{\mathrm{H}^{-1}\left(\theta_{\mathrm{L}, 0},+\right)}\left[\mathrm{r}\left\{\mathrm{H}(\mathrm{x}) \mid \mathrm{m}_{0}\right\}-\mathrm{r}\left\{\mathrm{H}(\mathrm{x}) \mid \mathrm{m}_{1}\right\}\right](\mathrm{x}+\gamma(1-\mathrm{x})) \mathrm{dF}_{0}(\mathrm{x})- \\
& \int_{\theta_{\mathrm{L}, \Pi}}^{\theta_{\mathrm{L}, 0}}\left[\mathrm{r}\left(\mathrm{x} \mid \mathrm{m}_{0}\right)-\Psi\right](\mathrm{x}+\gamma(1-\mathrm{x})) \mathrm{dF}_{0}(\mathrm{x})- \\
& \int_{\theta_{\mathrm{L}, \mathrm{I}}}^{\theta_{\mathrm{L}}}\left[1-\beta \frac{\mathrm{R}}{\mathrm{L}}\right][(1-\gamma)(1-\mathrm{x})] \mathrm{dF}_{0}(\mathrm{x})
\end{aligned}
$$

Note that profits have to be calculated separately across those firms that succeeded and those that failed, since the regions of integration will differ. The calculation over multiple time periods is presented later, but equation (15) demonstrates that a profit is possible over one time period (see Figure 4).

Relational banks have regions of potential monopoly gains because the cost of lending declines after the initial loan, due to a decrease in the cost of monitoring. These banks can also offer loans at a loss in the first period to borrowers with very low quality or to borrowers who would otherwise obtain a loan from a transactional bank, making up the loss in subsequent periods because of the potential for monopoly pricing gains.

The first term in equation (15) is the gain from the second loan to successful borrowers, described in Proposition Two as the additional amount obtained by charging up to the price of a first loan as costs decline. The second term is the interest loss from the first loan for successful borrowers, while the third term is the loss on the collateral for borrowers who default. To find the new lower bound for $\theta$, namely $\theta_{\mathrm{L}, \Pi}$, one can take the derivative with respect to $\theta_{\mathrm{L}, \Pi}$ of equation (15). Before pursuing this, there are other factors to address that will impact this calculation.

\subsection{Borderline Borrowers of Quality}

A similar strategy can be pursued for better quality borrowers, those near the boundary going from relational to transactional lending. By considering the potential gains in future periods, one may be able to extend loans to a broader group with higher quality. Again, Figure 4 displays this result. This strategy can be more risky in that it relies on transactional lenders not cutting profits and dropping prices for their loans. This would require a shift for all transactional lenders under the assumption of perfect competition, where we will assume that transactional lenders do not respond with a profit cut.

Proposition 4: It is possible for a relational bank to absorb an expected one-time loss for borrowers above the breakeven point in the initial period by compensating 
Figure 4: Regions of Potential Monopoly Pricing

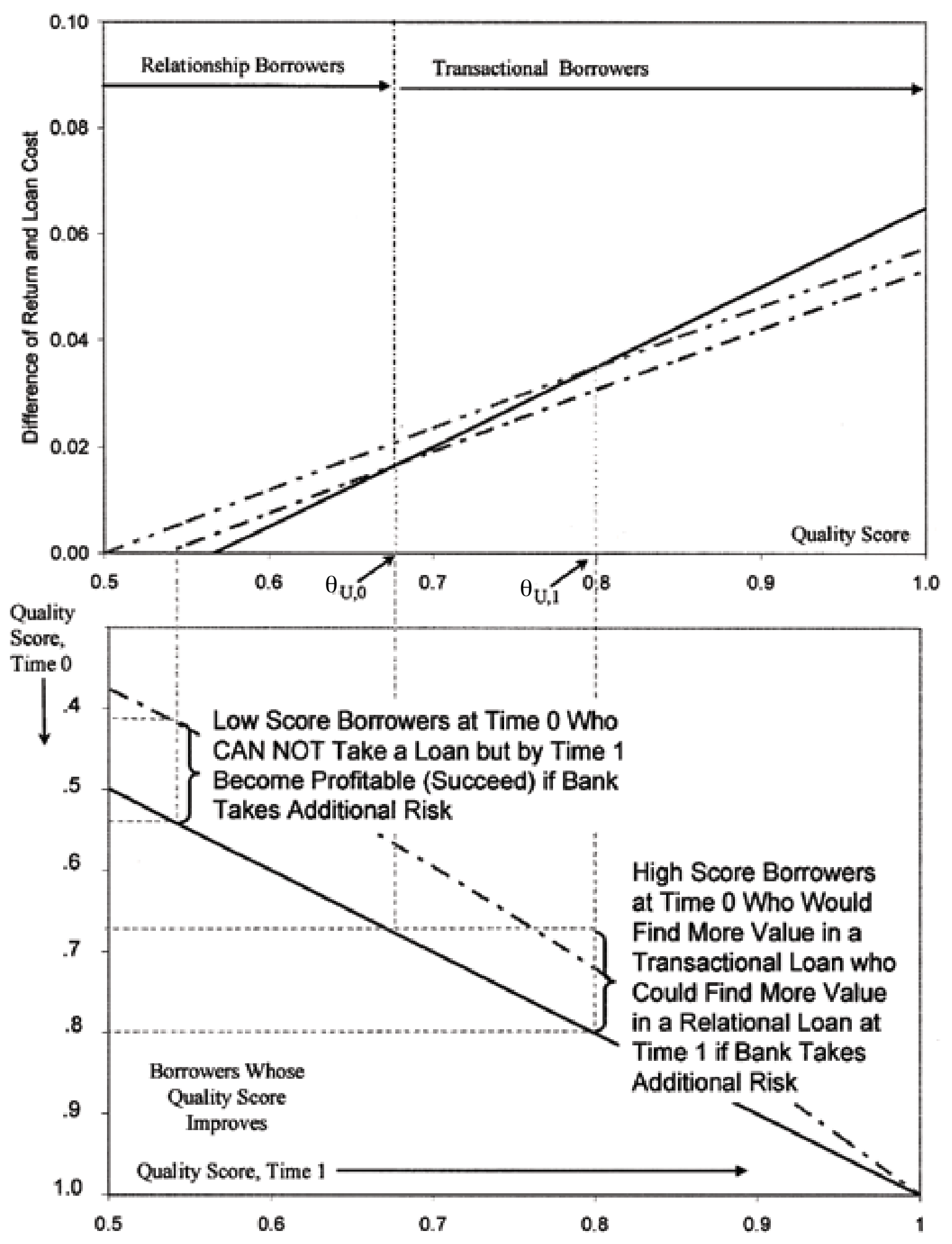


for the loss with an expected gain from those borrowers in later times for a net gain. To do this, the bank must extend loans above the quality level set in equation (8) up to a new upper quality level, $\theta_{\mathrm{U}, \Pi}$.

Proof: For one time period, this net gain is calculated as:

$$
\begin{aligned}
\text { Additional Profits (P4) }= & \int_{\mathrm{H}^{-1}\left\{\theta_{\mathrm{U}, 0},+\right\}}^{\mathrm{H}^{-1}\left\{\theta_{\mathrm{U}, \Pi},+\right\}}\left[\mathrm{r}\{\mathrm{H}(\mathrm{x}) \mid \mathrm{T}\}-\mathrm{r}\left\{\mathrm{H}(\mathrm{x}) \mid \mathrm{m}_{1}\right\}\right](\mathrm{x}+\gamma(1-\mathrm{x})) \mathrm{dF}_{0}(\mathrm{x})- \\
& \int_{\theta_{\mathrm{U}, 0}}^{\theta_{\mathrm{U}, \Pi}}\left[\mathrm{r}\left\{\mathrm{x} \mid \mathrm{m}_{0}\right\}-\mathrm{r}\{\mathrm{x} \mid \mathrm{T}\}\right](\mathrm{x}+\gamma(1-\mathrm{x})) \mathrm{dF}_{0}(\mathrm{x})- \\
& \int_{\theta_{\mathrm{U}, \mathrm{I}}, 0}\left[1-\beta \frac{\mathrm{R}}{\mathrm{L}}\right][(1-\gamma)(1-\mathrm{x})] \mathrm{dF}_{0}(\mathrm{x})
\end{aligned}
$$

The first term in equation (16) is the gain from the second loan to successful borrowers. The second term is the interest loss from the first loan for successful borrowers, while the third term is the loss on the collateral for borrowers who default. As in Proposition Three, to find the new lower bound for $\theta$, namely $\theta_{\mathrm{U}, \Pi}$, one can take the derivative with respect to $\theta_{\mathrm{U}, \Pi}$ of equation (16). Again, before pursuing this, there are other factors to address that will impact this calculation.

\subsection{Length of Stay with a Relational Banker}

To examine how long borrowers stay with a lender once a relationship has been established, we compute an expected length of a relationship predicated on a single assumption. We assume that once the relationship has been established, the borrower stays with the relationship lender because that lender offers a lower rate than any other lender. The only time to leave a relational lender would be when the borrower defaults or when the borrower's quality measure has increased to the point where the borrower can find other forms of financing, such as a transition to a transactional loan. The bulk of these calculations are presented in the appendix, but a summary is presented in this section so that we can have a measure of how long a borrower is expected to maintain a relationship, which is key to planning purposes for relationship bankers.

Section 4.3 described how quality measures were updated over time. To compute the expected length of a relationship with a bank, we make a simplifying assumption. We observe that increasing credit scores can only move a certain distance from their current values to improved credit scores, so a first order approximation to equation (1), $\theta_{\mathrm{f}, \mathrm{t}+1}=\mathrm{H}\left(\theta_{\mathrm{f}, \mathrm{t}+1}, \pm\right)$, is given by:

$$
\begin{aligned}
\theta_{\mathrm{f}, \mathrm{t}+1} & =\theta_{\mathrm{f}, \mathrm{k}}+\alpha\left(1-\theta_{\mathrm{f}, \mathrm{k}}\right) \text { if project successful } \\
& =\theta_{\mathrm{f}, \mathrm{k}}+\alpha \theta_{\mathrm{f}, \mathrm{k}} \quad \text { if project successful }
\end{aligned}
$$

where $0<\alpha<1$. 
If there were no anticipated improvements due to the relationship, at each point in time, we would have the expectation that the quality of the borrower would stay the same (some borrowers are successful, some borrowers fail, and the quality on average stays the same). Thus, from (17) we can compute that $E\left(\theta_{k+1}\right)=\theta_{k}$ if project successful, implying that a borrower with a transactional loan would always hover around their current quality score.

But relational borrowers always have a better chance of success due to the value of the relationship. This means that over time, the relational borrower will be expected to have their credit quality become better because of the value of the relationship. We find that the approximate average time a borrower with credit score $\theta_{0}$ at time zero can be expected to stay with a relational bank would be:

$$
\Phi=\frac{\ln \left(1-\theta_{U, 0}\right)-\ln \left(1-\theta_{0}\right)}{\ln \left(1-\gamma^{*} \alpha\right)}
$$

In this case, $\Phi$ is the expected amount of time that a borrower will remain with a relational lender, allowing for occasional project failures so that the borrowers credit score both increases and decreases over time.

\subsection{Strategies for Relational Lenders}

The final part of this paper examines strategies that a bank can undertake to maximize its profit making as part of the loan process. As described in the last several sections, there are multiple sources of such profits, termed extra-ordinary profits in this paper. Again, assuming perfect competition, transactional banks force each other to offer essentially the same rates to borrowers of the same quality. Relational banks, having higher costs, can only compete with transactional banks by offering more value to the borrower through monitoring, increasing the likelihood of success for a single project. At some point, the added cost outweighs the benefit, particularly to borrowers with a high probability of success in their projects. And under perfect competition, relational banks offer the same rates among themselves to new borrowers of the same quality. The leverage that the relational bank has is the ability to capitalize on the unique advantage it has with a borrower once a loan has been made. Costs of monitoring decline after the initial loan has been made, and this gives the lender a competitive advantage over all other lenders in establishing pricing.

Profits come from three different components captured over multiple time periods. As noted in the two previous sections, the calculation starts with losses taken in the initial period with two small sets of borrowers. At $t=1,2,3, \ldots, \Phi$ we can then expect to make monopoly profits in these two regions plus the monopoly profits for borrowers that were naturally relational borrowers without implementation of these strategies. At time zero, we take a loss, as shown in (19), to be offset by a gain, shown in (20). 
Expected Loss $=$

$\int_{\theta_{\mathrm{L}, \Pi}}^{\theta_{\mathrm{L}, 0}}\left[\mathrm{r}\left(\mathrm{x} \mid \mathrm{m}_{0}\right)-\Psi\right](\mathrm{x}+\gamma(1-\mathrm{x})) \mathrm{dF}_{0}(\mathrm{x})+\int_{\theta_{\mathrm{L}, \Pi}}^{\theta_{\mathrm{L}, 0}}\left[1-\beta \frac{\mathrm{R}}{\mathrm{L}}\right][(1-\gamma)(1-\mathrm{x})] \mathrm{dF}_{0}(\mathrm{x})+$

$\int_{\theta_{\mathrm{U}, 0}}^{\theta_{\mathrm{U}, \Pi}}\left[\mathrm{r}\left\{\mathrm{x} \mid \mathrm{m}_{0}\right\}-\mathrm{r}\{\mathrm{x} \mid \mathrm{T}\}\right](\mathrm{x}+\gamma(1-\mathrm{x})) \mathrm{dF}_{0}(\mathrm{x})+\int_{\theta_{\mathrm{U}, 0}}^{\theta_{\mathrm{U}, \Pi}}\left[1-\beta \frac{\mathrm{R}}{\mathrm{L}}\right][(1-\gamma)(1-\mathrm{x})] \mathrm{dF}_{0}(\mathrm{x})$

$$
\begin{aligned}
\sum_{\mathrm{k}=1}^{\Phi} & \left\{\int_{\mathrm{H}^{-\mathrm{k}}\left(\theta_{\mathrm{L}, 0},+\right)}^{\mathrm{H}^{-\mathrm{k}}\left(\theta_{\mathrm{U}, 0},+\right)}\left\{\mathrm{r}\left[\mathrm{H}^{\mathrm{k}}(\mathrm{x},+) \mid \mathrm{m}_{0}\right] \mathrm{r}\left[\mathrm{H}^{\mathrm{k}}(\mathrm{x},+) \mid \mathrm{m}_{\mathrm{k}}\right]\right\}(\mathrm{x}+\gamma(1-\mathrm{x}))^{\mathrm{k}+1} \mathrm{dF}_{0}(\mathrm{x})+\right. \\
& \left.\int_{\mathrm{H}^{-\mathrm{k}}\left(\theta_{\mathrm{L}, 0},+\right)}^{-\mathrm{k}\left(\theta_{\mathrm{L}, \Pi},+\right)}\left\{\mathrm{r}\left[\mathrm{H}^{\mathrm{k}}(\mathrm{x},+) \mid \mathrm{m}_{0}\right]-\mathrm{r}^{\mathrm{k}}(\mathrm{x},+) \mid \mathrm{m}_{\mathrm{k}}\right]\right\}(\mathrm{x}+\gamma(1-\mathrm{x}))^{\mathrm{k}+1} \mathrm{dF}_{0}(\mathrm{x})+ \\
\mathrm{H}^{-\mathrm{k}}\left\{\theta_{\mathrm{U}, \Pi},+\right\} & \left.\left.\mathrm{r}\left[\mathrm{H}^{\mathrm{k}}(\mathrm{x},+) \mid \mathrm{T}\right]-\mathrm{r}\left[\mathrm{H}^{\mathrm{k}}(\mathrm{x},+) \mid \mathrm{m}_{\mathrm{k}}\right]\right\}(\mathrm{x}+\gamma(1-\mathrm{x}))^{\mathrm{k}+1} \mathrm{dF}_{0}(\mathrm{x})\right\}
\end{aligned}
$$

The profit function, Net Profit $(N P)=$ Expected Gain - Expected Loss, is in itself a function of the choices $\theta_{\mathrm{L}, \Pi}, \theta_{\mathrm{U}, \Pi}$, and $\mathrm{m}_{0}$ (the latter of course, relies on how it impacts $\gamma\left[\mathrm{m}_{0}\right]$. It is also a function of the number of time periods used in the calculation (in other words, the number of periods used by the relational bank for its time horizon in planning).

A simpler view of the expected loss and gain comes from recognizing that the range of integration extends across $\theta_{\mathrm{L}, \Pi}$ to $\theta_{\mathrm{U}, \Pi}$, with subtractions for double counting.

Proposition 5: Profit maximization, maximization of NP = Expected Gain Expected Loss, follows through the solution of:

$\partial \mathrm{NP} / \partial \theta_{\mathrm{L}, \Pi}=0, \partial \mathrm{NP} / \partial \theta_{\mathrm{U}, \Pi}=0$, and $\partial \mathrm{NP} / \partial \mathrm{m}_{0}=0$

subject to the appropriate second order conditions. Iterative solutions are necessary to find $\theta_{\mathrm{L}, \Pi}, \theta_{\mathrm{U}, \Pi}$, and $\mathrm{m}_{0}$.

\subsection{Unchanging Borrower Quality}

Sharpe and several others employ a particular model where the quality of the borrower is unchanging, which is a special case of the model described here. If we restrict the model to this special case, we can find two of the necessary parameters, $\theta_{\mathrm{L}, \Pi}$ and $\theta_{\mathrm{U}, \Pi}$ directly, noting some interesting characteristics. It is not possible to solve directly for the remaining parameter, $\mathrm{m}_{0}$, but the form of the equation that 
would be used to find $\mathrm{m}_{0}$ is also instructive. Derivation of these parameters is given in the Appendix to this paper.

Proposition 6: When borrower quality is unchanging, the optimal lower end of the borrowing range depends strictly on the relationship of the cost of lending to the expected rate of return for the borrower, adjusted by the expected improvement in the likelihood of success due to monitoring.

The optimal lower bound quality score, $\theta_{\mathrm{L}, \Pi}$, for lending is the value that satisfies:

$$
\begin{gathered}
(1-\gamma)\left(1-\theta_{\mathrm{L}, \Pi}\right)\left(\Psi-\mathrm{r}_{0}\right) \cong\left(\mathrm{r}_{0}-\overline{\mathrm{r}}\right) \\
\text { where } \overline{\mathrm{r}}=(1-\gamma)\left(1-\theta_{\mathrm{L}, \Pi}\right) \sum_{\mathrm{k}=0}^{\Phi} \mathrm{r}_{\mathrm{k}}\left(\theta_{\mathrm{L}, \Pi}+\gamma\left(1-\theta_{\mathrm{L}, \Pi}\right)\right)^{\mathrm{k}}
\end{gathered}
$$

Equation (22) has all values $r_{k}$ determined at $\theta_{L, \Pi}$, so the solution of (22) is not as direct as it appears, but rather, requires an iterative solution.

There are some very intuitive results that come from equation (22). The average cost of monitoring is declining, so that if the time horizon is extended sufficiently far, it might be possible that the average rate that would be charged under perfect competition. If all lenders had the same information, it would decline sufficiently so that the expected loss from the first period is equal to the expected gain for a large number of time periods.

Proposition 7: When borrower quality is unchanging, the optimal upper end of the borrowing range depends strictly upon the relationship of the relative difference in the cost of monitoring to the cost of a transactional loan, adjusted by the expected improvement in the likelihood of success due to monitoring.

When borrower quality is unchanging, the upper bound, $\theta_{\mathrm{U}, \Pi}$, to which relational lenders should extend credit by taking a loss in the first period, is the value that satisfies:

$$
\begin{gathered}
(1-\gamma)\left(1-\theta_{\mathrm{U}, \Pi}\right)\left(\mathrm{r}_{0}-\mathrm{r}_{\mathrm{T}}\right) \cong\left(\mathrm{r}_{\mathrm{T}}-\overline{\mathrm{r}}\right) \\
\text { where } \overline{\mathrm{r}}=(1-\gamma)\left(1-\theta_{\mathrm{U}, \Pi}\right) \sum_{\mathrm{k}=0}^{\Phi} \mathrm{r}_{\mathrm{k}}\left(\theta_{\mathrm{U}, \Pi}+\gamma\left(1-\theta_{\mathrm{U}, \Pi}\right)\right)^{\mathrm{k}}
\end{gathered}
$$

Equation (23) has all values $r_{k}$ and $r_{r}$ determined at $\theta_{U, \Pi}$, so the solution of (23) is not as direct as it appears, but rather, requires an iterative solution.

Equation (23) shows that the upper bound for the relational lenders is a function of the average monitoring costs over $\Phi$ time periods. Since the average monitoring cost can be reduced over many time periods, the upper bound is increased, and a larger share of the borrowers can be taken if the bank expects a longer time horizon.

Note that neither of these values is dependent upon the probability distribution of the quality measure. Each is a function of the tradeoff between the relative cost 
of making the loan with the expected improvement that the lender can provide to the borrower. Even though we can summarize how to solve explicitly for these two values, a similar looking, closed form solution for the value $\mathrm{m}_{0}$ eludes us because of the complexity of the function. This is so despite the fact that we have fixed the quality of the borrower to never change.

\section{Empirical and Policy Implications}

There are numerous empirical and policy implications for our model. Each is discussed below. Informational monopoly rents no longer strictly accrue to relational lenders for all borrowers, as noted by Sharpe (1990). High credit quality firms may obtain better loan rates by switching to a transactional lender. This result is consistent with the results of Repullo \& Suarez (2004). With the extension of our model to multiple time periods, we are also able to show that there is no incentive for high quality firms that begin with a transactional lender to ever transfer to a relational lender, given the higher borrowing rates based upon higher monitoring costs. Therefore, they have to be captured by the relational bankers by taking greater risk with these borrowers in early time periods. Numerous studies have shown that larger banking organizations offer greatly reduced interest rates to small businesses relative to their community bank counterparts, i.e., Berger and Udell (1996); Berger, Rosen, and Udell (2001); and Carter, McNulty, and Verbrugge (2004).

Interest rates charged to small firms are a direct function of costs of lending and the quality of the borrower. Thus, banks incorporate risk based pricing. Survey evidence of risk based pricing by banks is provided by Cowan and Cowan (2006). This pricing leads to the possibility for either increases or decreases in interest rates for borrowers over time.

A key assumption in our model is that monitoring adds value. Relational lenders have the possibility of impacting the probability of firm success. Thus, they should experience fewer difficulties given the same credit grade with transactional lenders, all else held equal. Evidence for the validity of this assumption is apparent in the community investment literature. In addition, there is a significant amount of anecdotal evidence from small business lenders, suggesting that practitioners believe this assumption to hold. However, with the exception of Boot and Thakor (2000), the value of monitoring is not considered in the previous literature.

Our model suggests that higher risk credits will gravitate toward banks that engage in relationship lending. Berger (2004) had argued that this is, in fact, the current state of the industry.

Our model indicates that relationship banking affords lenders with opportunities to strategically price relationship loans. Loans that are subsidized initially may be profitable with relationship longevity. Empirical support for such a result is provided by Petersen and Rajan (1995), as well as Cetorelli nd Gambera (2001). This point is crucial in understanding the typical view, that as higher quality borrowers may benefit most from Basel II, this may not also be true if relational banks compete and offer other advantages in taking these borrowers from transactional lenders. 
There are several ways to test our model predictions with the data. The ability to test our propositions to a large degree requires information that is not publicly available. We specifically need to identify the operational characteristics of banks related to credit scoring, which is not publicly available information. Nevertheless, both case studies and survey methodologies provide opportunities to investigate our predictions. For example, using survey data from 1977 through 1989, Berlin and Mester (1998) find that bank loan pricing practices have historically been too insensitive to credit risk. If our propositions hold, then a more recent dataset should exhibit greater sensitivity to credit risk by banks in general.

\section{Conclusion}

In summary, we provided a theoretical model of small business lending within a competitive environment that incorporates technological and regulatory changes. Borrower quality and lending costs interact to attract borrowers to banks that exhibit specific modes of lending (i.e., transactional versus relationship). Our model suggests that interest rates offered to borrowers may either increase or decrease over time, which is intuitively appealing. Based on the assumption that banks add value through monitoring, we show that banks may pursue a broader range of borrowers due to reduced risk. In our model, the improvement offered by the bank depends on how much the bank is willing to invest in the relationship. In general, we find that there is a unique market niche for both transactional and relationship lenders, but a grey area in between that depends on the level of investment the relationship lender wishes to make in the relationship. We also show that banks that take advantage of internal risk based models are able to reduce small business loan rates.

The proposed model differs from previous theoretical models in several significant ways. We look at information about firms that is available to banks and the costs associated with obtaining that information. Whereas previous models assume that banks have no information about businesses in the first time period, our model assumes that banks initially have some information specific to a firm. Additionally, we assume that the quality of a firm changes over time due to the success of projects. Information about a firm develops over a longer time frame than two periods, especially since the quality of the firm is changing. Banks strategically consider the impact of maintaining a long-term relationship with a firm.

Although our model is yet to be tested to a large degree, our predictions appear to be consistent with the trends reflected in the small business data. For example, small business credit card competition is driving down loan rates at the large institutions that offer these cards. Several extensions to this paper are possible, eventually providing for a richer model. In addition, this model restricts a lender to a single type of lending; i.e., either relationship or transaction. It is clear that lenders might adopt a strategy that incorporates elements of both relationship lending and transactional lending, depending of course, upon the quality of the borrower. A natural extension is thus adding a third type of competitive lender that uses quality thresholds in determining the degree of monitoring utilized. 
Author statement: Adrian M. Cowan is affiliated with the Bill Greehey School of Business at the St. Mary's University E-mail: acowan@stmarytx.edu. Charles D. Cowan's affiliation is with The University of Alabama at Birmingham c.cowan@ analyticfocus.com.

\section{References}

Akhavein, J., Frame, W.S., and White, L J., (2005). The diffusion of financial innovation: An examination of the adoption of small business credit scoring by large banking organizations. Journal of Business, 28, 577-596.

Allen, F., Caaretti, E., and Marquez, R., (2006). Credit market competition and capital regulation. Working Paper, Federal Reserve Board, Finance and Economics Discussion Series, 2006-11.

Berger, A. N., (2004). Potential competitive effects of Basel II on Banks in SME Credit Markets in the United States. Working Paper, Federal Reserve Board, Finance and Economics Discussion Series, 2004-12.

Berger, A.N., Rosen, R.J., and Udell, G.F., (2001). Does market size structure affect competition? The case of small business lending. Working Paper, Federal Reserve Board.

Berger, A.N., and Udell, G.F., (1995). Relationship lending and lines of credit in small firm finance. Journal of Business, 68, 351-381.

Berger, A.N., and Udell, G.F., (1996). Universal banking and the future of small business lending. A. Saunders and I. Walter ed: Financial system design: The case for universal banking. Irwin Publishing, Burr Ridge, IL, 559-627.

Berger, A.N., and Udell, G.F., (2002). Small business credit availability and relationship lending: The importance of bank organizational structure. Economic Journal, 112, 32-53.

Berlin, M., and Mester, L.J., (1998). On the profitability and cost of relationship lending. Journal of Banking and Finance, 22, 873-897.

Blöchlinger, A., and Leippold, M., (2006). Economic benefit of powerful credit scoring. Journal of Banking and Finance, 30, 851-873.

Boot, A.W.A., and Thakor, A.V., (1994). Moral hazard and secured lending in an infinitely repeated credit market game. International Economic Review, 35, 899-920.

Boot, A.W.A., and Thakor, A.V., (2000). Can relationship banking survive competition? Journal of Finance, 55, 679-713.

Carter, D.A., McNulty, J.E., and Verbrugge, J.A., (2004). Do small banks have an advantage in lending? An examination of risk-adjusted yields on business loans at large and small banks. Journal of Financial Services Research, 25, 233-252.

Cetorelli, N., and Gambera, M., (2001). Banking market structure, financial dependence and growth: International evidence from industry data. Journal of Finance, 56, 617-648.

Cole, R.A., Goldberg, L.G., and White, L.J., (2004). Cookie cutter vs. character: The microstructure of small business lending by large and small banks. Journal of Financial and Quantitative Analysis, 39, 227-251. 
Cowan, C. D., and Cowan, A. M., (2006). A Survey Based Assessment of Financial Institution Use of Credit Scoring for Small Business Lending. Research Study, Banking and Financial Economic Research, Small Business Association Office of Advocacy.

Diamond, D.W., (1984). Financial intermediation and delegated monitoring. Review of Economic Studies, 51, 393-414.

Diamond, D.W., (1991). Monitoring and reputation: The choice between bank loans and directly placed debt. Journal of Political Economy, 99, 689-721.

Diamond, D.W., (1996). Financial intermediation as delegated monitoring: A simple example. Federal Reserve Bank of Richmond Economic Quarterly, 82, 51-66.

Frame, W.S., Srinivasan, A., and Woosley, L., (2001). The effect of credit scoring on small business lending. Journal of Money, Credit, and Banking, 33, 813825.

Greenbaum, S.I., Kanatas, G., and Venezia, I., (1989). Equilibrium loan pricing under the bank-client relationship. Journal of Banking and Finance, 221235.

Mester, L.J., (1997). What's the point of credit scoring. Federal Reserve Bank of Philadelphia Business Review, 3-16.

Petersen, M.A., and Rajan, R.G., (1994). The benefits of lending relationships: Evidence from small business data. The Journal of Finance, 49, 3-37.

Petersen, M.A., and Rajan, R.G., (1995). The effect of credit market competition on lending relationships. Quarterly Journal of Economics, 110, 407-443.

Rajan, R.G., (1992). Insiders and outsiders: The choice between informed and arm's-length debt. The Journal of Finance, 47, 1367-1400.

Ramakrishnan, S., and Thakor, A.V., (1984). Information reliability and a theory of financial intermediation. Review of Economic Studies, 51, 415-432.

Repullo, R., and Suarez, J., (2004). Loan pricing under Basel capital requirements. Journal of Financial Intermediation, 13, 496-521.

Sharpe, S.A., (1990). Asymmetric information, bank lending, and implicit contracts: A stylized model of customer relationships. The Journal of Finance, 45, 1069-1087. 


\section{Appendix: Profit Maximization Parameters When Quality Measures Do Not Change}

\section{A1: A Summary of Model Components}

\begin{tabular}{|c|c|}
\hline$\theta_{\mathrm{f}, \mathrm{t}}$ & the observed quality of a firm $\mathrm{f}$ in time period $\mathrm{t}, 0 \leq \theta_{\mathrm{f}, \mathrm{t}} \leq 1$ \\
\hline $\mathrm{F}(\theta)$ & $\begin{array}{l}\text { cumulative distribution of } \theta_{\mathrm{f}, \mathrm{t}} \text { over all firms applying for } \\
\text { loans, } \mathrm{f}=1, \ldots, \mathrm{N} \text { ordered by credit quality }\end{array}$ \\
\hline $\begin{array}{l}\theta_{\mathrm{f}, \mathrm{t}+1}=\mathrm{H}\left(\theta_{\mathrm{f}, \mathrm{t}},+\right) \\
\theta_{\mathrm{f}, \mathrm{t}+1}=\mathrm{H}\left(\theta_{\mathrm{f}, \mathrm{t}},-\right)\end{array}$ & $\begin{array}{l}\text { quality at time } t+1 \text { is function of quality at time } t \text { and success } \\
\text { or failure at time } t ; \\
+ \text { for a success; }- \text { for a failure }\end{array}$ \\
\hline $\mathrm{C}_{\mathrm{R}}=\mathrm{m}_{\mathrm{t}}$ & $\begin{array}{l}\text { costs for relational lending for } \mathrm{t}=0,1,2,3, \ldots \\
\mathrm{m}_{\mathrm{t}} \text { is the expenditure by the bank to monitor a firm; } \\
\mathrm{m}_{\mathrm{t}}<\mathrm{m}_{\mathrm{t}-1}\end{array}$ \\
\hline $\mathrm{C}_{\mathrm{R}}=\mathrm{T}$ & $\begin{array}{l}\text { costs for transactional lending for } \mathrm{t}=0,1,2,3, \ldots, \\
\mathrm{T}<\mathrm{m}_{\mathrm{t}} \text { for all } \mathrm{t}\end{array}$ \\
\hline$\gamma\left[\mathrm{m}_{0}\right]$ & $\begin{array}{l}\text { the proportion of improvement to a project that can be applied } \\
\text { to increase the likelihood of repay; } \\
\gamma\left[\mathrm{m}_{0}\right] \equiv 0 \text { for transactional lenders. }\end{array}$ \\
\hline $\mathrm{p}_{\mathrm{f}, \mathrm{t}}=\theta_{\mathrm{f}, \mathrm{t}}+\gamma\left[\mathrm{m}_{0}\right]^{*}\left(1-\theta_{\mathrm{f}, \mathrm{t}}\right)$ & probability that borrower will repay \\
\hline$\Psi$ & rate of return to borrower for a project that is funded \\
\hline$r_{m}$ & cost of funds to the bank \\
\hline $\mathrm{r}_{\mathrm{c}, \mathrm{j}}, \mathrm{r}_{\mathrm{T}, \mathrm{k}}=\mathrm{r}_{\mathrm{T}}, \mathrm{r}_{\mathrm{C}, \mathrm{k}}=\mathrm{r}_{\mathrm{k}}$ & $\begin{array}{l}\text { interest rate to be charged to the borrower by bank type } \mathrm{C} \text { in } \\
\text { time period } \mathrm{k} \text {, abbreviated for transactional and relational } \\
\text { lenders }\end{array}$ \\
\hline $\mathrm{L}$ & amount of the loan \\
\hline $\mathrm{R}$ & amount of collateral underlying the loan \\
\hline$\beta$ & recovery rate on collateral \\
\hline$\alpha$ & $\begin{array}{l}\text { proportional increase } \backslash \text { decrease in quality score after project } \\
\text { success } \backslash \text { failure }\end{array}$ \\
\hline$\Phi$ & $\begin{array}{l}\text { expected amount of time that a borrower will remain with a } \\
\text { relational lender }\end{array}$ \\
\hline
\end{tabular}

